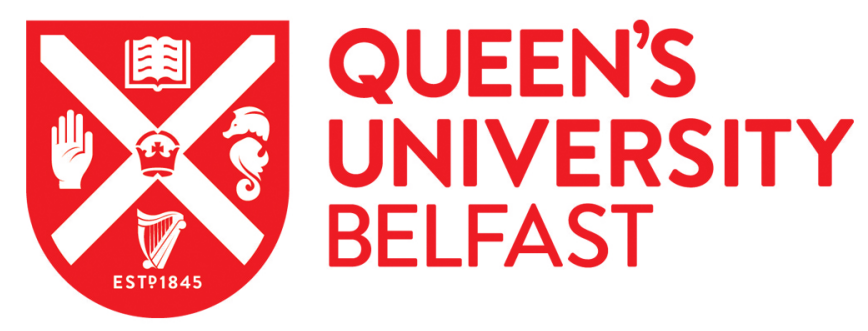

\title{
Homelessness and people with intellectual disabilities: A systematic review of the international research evidence: Homelessness and people with intellectual disabilities
}

Brown, M., \& Mccann, E. (2020). Homelessness and people with intellectual disabilities: A systematic review of the international research evidence: Homelessness and people with intellectual disabilities. Journal of Applied Research in Intellectual Disabilities. https://doi.org/10.1111/jar.12815

Published in:

Journal of Applied Research in Intellectual Disabilities

Document Version:

Peer reviewed version

Queen's University Belfast - Research Portal:

Link to publication record in Queen's University Belfast Research Portal

Publisher rights

Copyright 2020 Wiley. This work is made available online in accordance with the publisher's policies. Please refer to any applicable terms of use of the publisher.

\section{General rights}

Copyright for the publications made accessible via the Queen's University Belfast Research Portal is retained by the author(s) and / or other copyright owners and it is a condition of accessing these publications that users recognise and abide by the legal requirements associated with these rights.

Take down policy

The Research Portal is Queen's institutional repository that provides access to Queen's research output. Every effort has been made to ensure that content in the Research Portal does not infringe any person's rights, or applicable UK laws. If you discover content in the Research Portal that you believe breaches copyright or violates any law, please contact openaccess@qub.ac.uk. 
Homelessness and people with intellectual disabilities: A systematic review of the international evidence

Michael Brown PhD RGN RNLD FHEA FRCN

Professor of Nursing, School of Nursing and Midwifery, Queen's University Belfast,

Northern Ireland, United Kingdom

Email: m.j.brown@qub.ac.uk

Edward McCann PhD RN RPN RNT FHEA

Assistant Professor, School of Nursing and Midwifery, University of Dublin, Trinity College, Dublin, Ireland.

Email: mccanned@tcd.ie

Tel: +35318964161 


\section{Abstract \\ Background}

People with intellectual disabilities can experience homelessness and some of the reasons differ from the general homeless population. Specific policy and practice responses are required.

\section{Method}

A systematic review of studies examining homelessness among people with intellectual disabilities utilizing CINAHL, MEDLINE, PsycINFO and Sociological Abstracts databases from inception to November 2019.

\section{Results}

The search produced 259 papers and following screening a total of 13 papers were included in the review. The themes identified were (i) pathways into homelessness, (ii) experiencing homelessness, and (iii) routes out of homelessness.

\section{Conclusions}

People with ID become homeless due to multifactorial issues. The identification of people within homeless services and their care and support concerns remains challenging, impacting upon the provision of assessments, interventions, care and supports. Psychosocial assessments, interventions and supports are necessary to assist people with ID to leave homelessness.

\section{Keywords:}

Homelessness, intellectual disabilities, social exclusion, stigma, health needs, supports 


\section{Homelessness and people with intellectual disabilities: A systematic review of the international research evidence}

\section{INTRODUCTION}

There is a growing global focus and concern regarding the issue of homelessness. Homelessness involves living between shelters, in the homes of friends, on the streets, in emergency accommodation and in boarding houses without a private bathroom and security of tenure (Crisis, 2018). The World Health Organisation defines homelessness as living in housing that is below the minimum standard or lacks secure tenure (World Health Organisation, 2018). It is estimated that 150 million people are homeless world-wide, however exact prevalence remains difficult to determine (Busch-Geertsema, Culhane \& Fitzpatrick, 2016; Bainbridge \& Carrizales, 2017; Wilson, McCloughen, Parr \& Jackson, 2019). Homeless people across age cohorts have been identified as experiencing poor self-reported health, increased access to health services and significant health-related needs (van Dongen, van Straaten, Wolf, Onwuteaka-Philipsen, van der Heide, Rietjens, \& van de Mheen, 2019). The pathways into homelessness are multifactorial and include poverty, conflict with the law, unemployment, low income, reduction in income, evictions, relationship breakdown, serious illness and natural disasters (Piat, Polvere, Kirst, Voronka, Zabkiewicz, Plante, Isaak, Nolin, Nelson, G. \& Goering, 2015; Levine, Proulx \& Schwartz, 2018; McCann \& Brown, 2019; Phipps, Dalton, Maxwell \& Cleary, 2019). It has been estimated that $30-40 \%$ of homeless adults have a cognitive impairment, including people with intellectual disabilities (ID) (Spence, Stevens \& Parks, 2004). In a systematic review focusing on homelessness and people with a range of cognitive impairments, the homeless groups identified were people with traumatic brain injury, learning difficulties, ID, autism spectrum disorder and attention deficit hyperactivity disorder. The review identified that across the cognitively impaired groups, there is inadequate recognition of co-occurring disorders and therefore the full extent of the needs, 
highlighting the necessity for additional resources and support (Stone, Dowling \& Cameron, 2019). The exact prevalence of homelessness within the ID population remains unclear, however estimates range from 12-39\% (Durbin, Isaacs, Mauer-Vakil, Connelly, Steer, Roy, \& Stergiopoulos, 2018). In addition, the risk factors and pathways resulting in homelessness for people with ID need to be fully understood and it has been suggested that there is no single factor that results in homelessness (Stone et al., 2019).

Most people with ID live at home with their family, however, some individuals live in congregated institutional and other supported living settings (Salmon, Garcia Iriarte, Donohoe, Murray, Singleton, Barrett, \& Dillon, 2019). In many countries across the world there have been significant changes and developments with moves away from institutional models of care to care and support being provided in the community, enabling people with ID to live independently. However, congregated care remains evident in some countries (Woodman, Mailick, Anderson, \& Esbensen, 2014). As the ID population ages more people may require access to care and support from education, housing, social welfare and healthcare services (Cronin \& Bourke 2017). Many people with ID are significantly disadvantaged in relation to education attainment, employment opportunities, dependence on state welfare and benefits and public housing (Ditchman, Kosyluk, Lee, \& Jones, 2016; Hourigan, Fanaghan, \& Caraiosa, 2018). Collectively these issues contribute to poverty, low social status and standing, limited employment opportunities and community participation (Park, Nam \& Park, 2017; Maroto, Pettinicchio, Patterson, 2019).

From a health perspective, people with ID are further disadvantaged by their diverse physical and mental health conditions that contribute to their poor health and premature death (Cooper, McLean, Guthrie, McConnachie, Mercer, Sullivan, \& Morrison, 2015; HughesMcCormack, Rydzewska, Henderson, MacIntyre, Rintoul, \& Cooper, 2018). Physical health conditions are particularly common and include for example, respiratory disorders, epilepsy, 
gastrointestinal conditions, cardiovascular disease (Truesdale \& Brown 2017) Mental ill health is common due to issues such as adverse life events and environmental stressors including sexual abuse, violence and poverty (Koswloski, Klein, Arnold, Koesters, Schuetzwohl, Salize, \& Puschner, 2016). Diagnosing mental illness can be difficult due to communication deficits, physical health conditions, and diagnostic overshadowing (Whittle, Fisher, Reppermund, Lenroot, \& Trollor, 2018). As a consequence of their physical and mental health conditions, people with ID require access to health assessment and screening that identifies their distinct needs and to provide evidence-based interventions, treatments and supports (Robertson, Hatton, Emerson, \& Baines, 2014). Support is required to facilitate the care journey through the healthcare system, thereby ensuring that they have equality of access and improved health outcomes (Williamson, Contreras, Rodriguez, Smith, \& Perkins, 2017). Significant gaps still exist in the full understanding of these pertinent issues upon homelessness. Therefore, the aims of this systematic review are to more fully understand the factors that lead to homelessness for people with ID, their experiences while homeless and their support needs out of homelessness.

\section{METHOD}

\subsection{Review questions}

The specific questions that the systematic review sought to address were:

1. What are the factors that lead into homelessness for people with ID?

2. What are the experiences of people with ID when homeless?

3. What are the necessary supports to enable people with ID to exit homelessness?

\subsection{Search strategy}


The systematic review included empirical studies that used quantitative, qualitative and mixed research methods. A subject librarian was consulted to help with the literature search process. The databases utilized in the search were CINAHL, MEDLINE, PsycINFO and Sociological Abstracts. The search terms included: homeless* AND intellectual disab* OR mental retard* OR developmental disab* OR mental handicap* OR learning disab*. The data were published from inception to November 2019. The inclusion criteria were limited to academic journals, peer reviewed empirical studies written in English and included homeless people with an intellectual disability. Papers that specifically focused on traumatic brain injury, mental illness, special educational needs and learning difficulties were excluded. Included studies had to focus on the homeless experiences of people with intellectual and developmental disabilities; those that did not meet the criteria were rejected. An example of the search strategy used in one electronic database is shown in Table 1.

***Insert Table 1 here***

\subsection{Study selection}

The PRISMA process for reporting the results of the searches was used (Moher, Shamseer, Clarke, Gherisa, Liberati \& Pettigrew, 2015) (Figure 1). The searches revealed 259 cumulative hits across all of the databases. The computer programme Endnote was used in the management of the search results (Clarivate Analytics 2018). Two independent reviewers screened the titles for relevance and duplicates were removed leaving 68 papers. Following a review of the abstracts by the two reviewers, a total of 35 full text articles were assessed against the eligibility criteria and a further 23 excluded, leaving a total of 12 papers. Full text papers were screened independently be the reviewers and then jointly to resolve and disagreements. Studies were included if they specifically addressed factors leading to homelessness, the experiences of people with ID when homeless and the supports required to exit homelessness. The main 
reasons for exclusion were that the study sample included homeless people with learning difficulties, mental illness or youth with special education needs. A further paper was identified by hand searching, leaving a total of 13 included in the full review and synthesis.
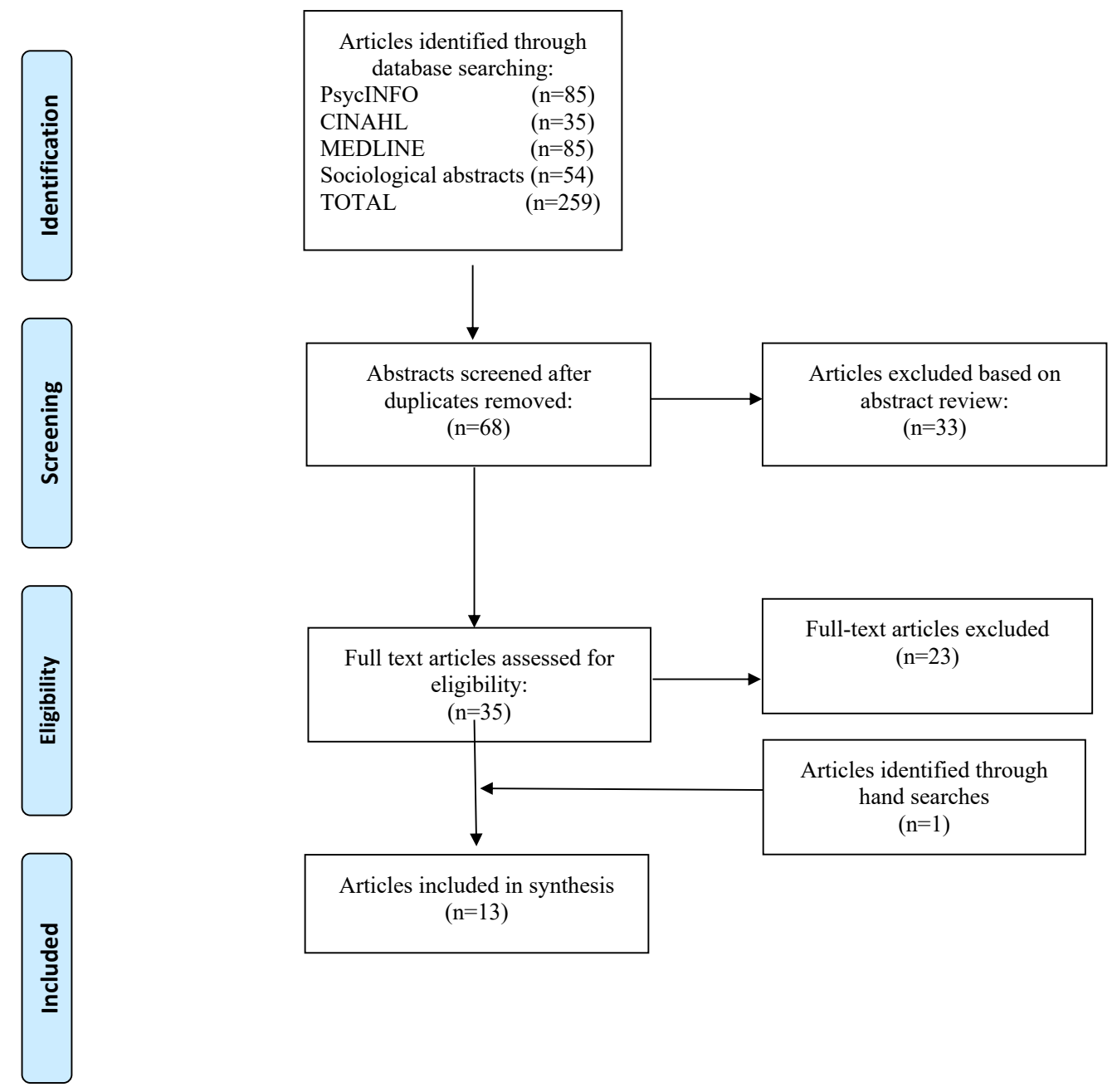

Figure 1: PRISMA flowchart of search strategy and outcome (Moher et al. 2015) 


\subsection{Study characteristics}

The thirteen studies focused on the aims of the systematic review, as set out in Table 2 . The studies were undertaken across a wide range of countries including Japan $(n=3)$, Netherlands $(\mathrm{n}=3)$, United Kingdom (UK) $(\mathrm{n}=2)$, Canada $(\mathrm{n}=1)$, United States (US) $(\mathrm{n}=2)$, India $(\mathrm{n}=1)$ and Mozambique $(n=1)$. Sample sizes ranged from 4 to 114 participants. Most studies $(n=7)$ used a mixture of methods involving interviews and standardised scales (van Straaten, Schrijvers, Van der Laan, Boersma, Rodenburg, Wolf \& Van de Mheen, 2014; Nishio, Yamamoto, Horita, Sado, Ueki, Watanabe, Uehara \& Shioiri T, 2015a; Nishio, Yamamoto, Ueki, Watanabe, Matsuura, Tamura, Uehara \& Shioiri, 2015b; Gouveia, Massanganhe, Mandlate, Mabunda, Fumo, Mocumbi \& de Jesus Mari, 2017; Nishio, Horita, Sado, Mizutani, Watanabe, Uehara \& Yamamoto, 2017; van Straaten, Rodenburg, van der Laan, Boersma, Wolf, van de Mheen, 2017; van der Laan, van Straaten, Boersma, Rodenburg, van de Mheen \& Wolf, 2018). One study used case records, interviews and standardised scales (Oakes \& Davies, 2008). Two studies used case records (Mercier \& Picard, 2011; Gowda, Gopika, Kumar, Manjunatha, Yadav, Sriniv, Dawn, Math, 2017) and three studies used semi-structured interviews (Morton \& Cunningham-Williams, 2009; Morton, Cunningham-Williams \& Gardiner, 2010; McKenzie, Murray, Wilson \& Delahunty, 2019).

$* * *$ Insert Table 2 here***

\subsection{Critical appraisal}

The two reviewers jointly appraised the included studies utilising a recognized quality assessment tool, the Critical Appraisal Skills Programme (CASP), as an evidence-based framework (Critical Appraisal Skills Programme 2013). This approach was chosen to allow for the synthesis of both qualitative and quantitative data to produce a systematic review of 
the research evidence. A range of questions were systematically applied to each of the studies (Table 3). Individual questions were scored zero, one or two from a possible overall score of twenty. Studies containing no information were given zero, a score of one for a limited amount of information and a score of two if the question was answered comprehensively (Rushbrooke, Murray \& Townsend, 2014). A total of eight studies achieved scores of 17 and above, indicating good quality and relevant information (Morton \& Cunningham-Williams 2009; van Straaten, Schrijvers, van der Laan, Boersma, Rodenburg, Wolf \& van de Mheen, 2014; Nishio et al., 2015a; Nishio et al., 2015b; Nishio et al., 2017; van Straaten et al., 2017; van der Laan et al., 2018; McKenzie et al., 2019). Scores of between 14 to 16 were given to three studies thereby showing deficits related to clarity of aims, recruitment issues, data collection and analysis (Oakes \& Davies, 2008; Morton et al. 2010; Gouveia et al. 2017). The remaining two studies had scores of thirteen or less indicating shortcomings on most questions (Mercier \& Picard, 2011; Gowda et al., 2017). Any disagreements regarding the quality assessment were discussed by the reviewers and consensus reached. All of the studies identified addressed the objectives of the systematic review and were therefore deemed suitable for inclusion.

\footnotetext{
***Insert Table 3 here***
}

\subsection{Data analysis and synthesis}

An analysis of the data was undertaken by the reviewers using an inductive process whereby the emergent themes were systematically identified within and across all the studies and coded by the two researchers. The content was grouped into concepts to allow for contrasts and comparisons to be made between and across the studies and the identified themes. The emergent themes were identified independently and then discussed, verified and agreed by the reviewers (Caldwell, Henshaw \& Taylor, 2011). 


\section{RESULTS}

3.1 Following detailed analysis, the main themes identified were (i) pathways leading into homelessness, (ii) experiencing homelessness, and (iii) routes out of homelessness.

\subsubsection{Pathways leading into homelessness}

A total of 11 studies addressed pathways into homelessness for people with ID. People with ID who are homeless are a sub-population of an already difficult group to identify. Therefore, the exact prevalence of people with ID who are homeless remains inconclusive (Morton \& Cunningham-Williams 2009; McKenzie et al., 2019). Three studies included in the current review attempted to identify prevalence rates (Oakes and Davies 2008; Mercier and Picard 2011; Van Straaten et al. 2014; Nishio et al. 2015a). The rates of homelessness among people with ID was 10\% (Oakes and Davies 2008); 30\% (Van Straaten et al. 2014); 34\% (Mercier and Picard 2011); and 40\% (Nishio et al. 2015a). People with ID are at greater risk of homelessness when compared with the non-ID population (Oakes and Davies 2008). In two studies, men with ID were more likely to become homeless and at an older age when compared to women with ID (Mercier and Picard 2011; Van Straaten et al. 2014). The identification of people with ID within the homeless population can be challenging. Different approaches were adopted across studies in an attempt to identify people with ID within homeless services. The most common approach adopted was self-report by potential study participants, following initial dentification by care staff. One study utilized a standardized screening by way of the Wechsler Adult Intelligence Scale (WAIS) (Nishio et al. 2015a). A further study sought to establish if the Learning Disability Screening Questionnaire would be an acceptable tool to identify homeless people with ID (McKenzie et al. 2019). 
Multiple issues were identified across all the studies that contributed to and led to homelessness for people with ID. The most common factors identified were the presence of significant education deficits, active mental illness, substance misuse, challenging behaviours and relationship breakdown (Morton \& Cunningham-Williams 2009, Mercier \& Picard 2011, Morton et al. 2010, Nishio et al. 2017, Oakes \& Davies 2008, van Straaten et al. 2014, van Straaten et al. 2017). Mental illness was identified in a number of the studies. In one study, $60 \%$ of the sample had mental illness and $56 \%$ had substance misuse issues (Mercier \& Picard 2011). Higher rates of somatization and depression were identified with homeless people with ID twice as likely to experience substance misuse with alcohol being the most commonly used substance (van Straaten et al. 2014). In a Japanese study, over $70 \%$ of homeless people with ID had mental health conditions including depression, post-traumatic stress disorder (PTSD), mood disorder and alcohol dependence (Nishio et al. 2015a). In another study, $42 \%$ of all the participants had a mental illness and $16 \%$ experiencing co-occurring ID and mental illness by way of schizophrenia, mood disorder, anxiety disorder, personality disorder and substance use (Nishio et al. 2015b). In a further study conducted in the Netherlands, 33\% of the study sample were utilizing mental health services (van Straaten et al. 2017). Several studies identified additional co-occurring health conditions including physical health issues (43\%) (Mercier \& Picard 2011), higher levels of smoking (Nishio et al. 2015b) and significant numbers accessing medical health care (69\%) (Van Straaten et al. 2017). Family relationship breakdown and subsequent homelessness appears to be related to the death of a family member or main carer and is a potential risk factor (Mercier and Picard 2011; Gouvia et al. 2017; Gowda et al. 2017; Nishio et al, 2017).

The ideal situation is to prevent people with ID from becoming homeless. For this to be realized, there needs to be nationally coordinated strategic policy approaches to homelessness and the inclusion of the specific needs of the ID population (McKenzie et al. 2019). In some 
studies, wider transcultural issues were identified as predetermining factors that may result in homelessness. For example, burden, shame and stigma due to having a family member with ID were identified as contributory factors leading to ejection from the family home (Gouvia et al. 2017; Gowda et al. 2017). Associated health co-morbidities, such as mental illness and challenging behavior, were also found to be negatively associated with homelessness (McKenzie et al. 2019), reducing the possibility of reintegration back into the family home (Gouvia et al. 2017; Gowda et al. 2017).

\subsubsection{Experiencing homelessness}

A total of 9 studies identified the experiences of people with ID when homeless. When people with ID become homeless a recurring issue is the estrangement from their families (Govia et al., 2017; Gowda et al., 2017). The factors leading to homelessness in the non-ID population, when compared to the ID population, appears to be related to mental illness and substance misuse leading to ejection from the family home. For the non-ID homeless, once treated, reintegration to the family home was achieved. However, reintegration back to the family home is in some cultures less likely for people with ID due to the enduring lifelong nature of the intellectual impairment and on-going dependence upon families for care and support (Govia et al. 2017; Gowda et al. 2017).

An important issue regarding supporting people with ID when homeless is the complexity of the decisions and options that need to be considered and addressed to facilitate the exit from homeless services. They include the range of community supports required, support to access to adult education, employment and workplace support and access to healthcare (Oakes \& Davies 2008; Morton \& Cunningham-Williams 2009; Gouvia et al. 2017). In one study undertaken in the United States (US) volunteering within the homeless agency was seen as beneficial to supporting reintegration back into the community by assisting with the 
development of life skills necessary for daily living and build resilience and self-esteem (Morton et al. 2010). Given the evidence of the extent of the extent of the co-occurring physical and mental health conditions that many people with ID experience, there is a need for access to initial assessments and screening when entering homeless services to comprehensively identify care and support needs (Nishio et al. 2015a; Nishio et al. 2015b; McKenzie et al. 2019). A significant number of people with ID were found to have co-existing physical and mental health conditions that had not previously been identified and treated, thereby impacting on their health and well-being and quality of life (van Straaten et al. 2017; van der Laan et al. 2018). For example, the most common physical health conditions were musculoskeletal and connective tissue complaints (31\%), dental conditions (24\%), visual impairments $(24 \%)$, respiratory disorders $(20 \%)$, gastro-intestinal disorders $(14 \%)$, podiatry complaints $(13 \%)$, and cardiovascular disorders (11\%) (van der Laan et al. 2018). Significant levels of smoking at $71 \%$ were identified in one study involving homeless people with ID (Nishio 2015b). Therefore, improved healthcare access and psychosocial supports specific to the needs of people with ID are indicated, including health screening, psychological therapies and treatments (van Straaten et al. 2017; van der Laan et al. 2018).

\subsubsection{Routes out of homelessness}

Of the 13 studies, a total of 9 addressed routes out of homelessness for people with ID. Integrated and well-coordinated support services are necessary to support people with ID out of homeless services due to their often-complex co-occurring needs (Nishio et al 2015a, Nishio et al. 2015b; van Straaten et al., 2017; van der Laan et al., 2018). Central to this is access to housing supports, mental health treatment and interventions and assertive community-based treatment programmes (Nishio et al. 2017). In order to provide pathways out of homelessness, 
appropriate and responsive physical and psychosocial interventions and supports need to be in place (van Straaten et al. 2017; van der Laan et al. 2018). A significant barrier that impacted upon the care and support provided to people with ID within homelessness services, and those exiting, related to the limited knowledge, skills and expertise of support staff regarding the specific needs and requirements of the population (McKenzie et al 2019). To help mitigate against these factors, wider policies and strategies need to include a focus on the needs of people with ID to ensure that education opportunities, discrimination, social exclusion, socioeconomic disparities and equality of healthcare access provision are identified and resources and support targeted (van Straaten et al., 2014; Gowda et al. 2017; Nishio et al., 2017). Consequently, education and practice development programmes need to focus on increasing the awareness that people with ID become homeless and the identification and assessment of their subsequent support needs requires a specific attention (Oakes \& Davies 2008, van Straaten et al. 2014; McKenzie et al. 2019). In terms of discharge from homelessness services and resettlement into the community, there is a need for effective inter-agency communication, information sharing and service collaboration thereby ensuring that care and support is coordinated and responsive in order to prevent a return to homelessness (van Straaten et al. 2014; Nishio et al. 2015a; Nishio et al. 2017; McKenzie et al. 2019). 


\section{DISCUSSION}

Important issues have emerged from this systematic review of the current evidence in relation to the experiences of homelessness people with ID. The key themes identified through this systematic review related to the factors that can lead to homelessness for people with ID, the unique experiences of people with ID when homeless and the range of supports necessary to enable them to exit homelessness and re-establish themselves within the community. The implications and relevance of the findings will be considered from the perspective of policy, practice development and education and future research developments.

\subsection{Policy implications}

Internationally and across many countries there is growing attention to the situation of people who are homeless (World Health Organization 2018). There is a need to recognize and respond effectively to the co-occurring factors that can lead to homelessness for people with ID and have in place preventative strategies. Some of the issues are similar to the non-ID population, while noting the distinct differences such as the impact and consequences of relationship breakdown, death of a family member or carer and risk of becoming homeless at an older age (McCann \& Brown 2019; Phipps et al 2019). Therefore, policy needs to take account of the complex and interrelated circumstances that can lead to homelessness for people with ID; they are multifactorial. Addressing these concerns requires sustained investment and development of services and supports to minimise the risk factors that predispose people with ID to homelessness such as family bereavement, mental health issues and challenging behaviours (Mercier \& Picard 2011; Nishio et al., 2015a, b; Gouda et al. 2017; McKenzie et al. 2019). Strategically, early intervention and prevention programmes are required, focusing on those most at risk, such as those experiencing a recent bereavement of a family member or carer with no or limited support Mericer \& Picard 2011). Many people with ID experience 
barriers when accessing healthcare and services appropriate to their needs (Pelleboer-Gunnink, van Oorsouw, van Weeghel, \& Embregts, 2017; Williamson et al., 2017). Given the range of physical health problems experienced by many people with ID, primary health care policy and services need to recognize and responds to the needs of those who are homeless through appropriate assessment and health screening, treatment and healthcare support plans (Emerson et al., 2016). Furthermore, mental health policy needs to take account of the extent of mental ill health and, in particular, the specific requirements of people ID and mental illness who are homeless (Nishio et al. 2015a, b; Nishio et al. 2017; Whittle, Fisher, Reppermund, \& Trollor, 2019). Investment and development are required to ensure that there is access to psychological treatments, interventions and social supports appropriate to the needs of individuals with ID who are homeless (Shankland, \& Dagnan, 2015; van Straaten et al. 2017; van der Laan et al. 2018).

\subsection{Implications for education and practice development}

Practitioners in care agencies, such as housing, education, health and social care, need to recognise that some people with ID become homeless and that on initial presentation it may not be apparent that the person has intellectual and developmental impairments. Furthermore, some people with mild ID may be unaware of their intellectual and cognitive impairment, thereby being unable to disclose this important information to ensure effective access to relevant care and support (McKenzie et al. 2019). Therefore, simple screening is required at the time of reception into homeless services to ensure that the necessary assistance and supports are tailored to the specific needs of the individual with ID (Nishio et al. 2015a; McKenzie et al. 2019). The initial focus of services, such as, housing, social work, primary care and specialist intellectual disability services, needs to focus on early identification of people with ID at risk of homelessness. 
As many people with ID live at home with their family, an important finding arising from this review is the significance of the bereavement of a family member or main carer. This major event may act as an early risk indicator that may be the precursor to a person with ID becoming homeless. Therefore, service planners and practitioners need to be aware of and alert to the potential significance and impact of such an event (Mercier \& Picard 2011). In order to minimise the possibility of homelessness, it is necessary to ensure that there are co-ordinated support services in place. Such services may need to include psychiatrists, clinical psychologists, occupational therapists, nurses and social workers, to enable responsive interprofessional care and support.

Practitioners have an important role in facilitating and co-ordinating access to housing, employment, education, day care, primary care and mental health services. This is important as the current evidence highlights that practitioners can bring about improvements in health, well-being and social circumstances (van Straaten et al. 2017; van der Laan et al. 2018). There is therefore an opportunity to develop new models of practice whereby practitioners from specialist ID services are based within homeless services thus ensuring collaborative and coordinated services and supports (van Straaten 2014).

To develop the knowledge, skills, attitudes and understanding of the requirements of people with ID who are homeless, there is a need to bring together the key stakeholders involved in providing services and supports. Given the multifarious range of issues and needs, shared interagency and interprofessional education is required. This will enable the development of information sharing about the services provided by the different agencies and identify future collaborations and shared practice (Mercier \& Picard 2011; Gouvia et al. 2017; Nishio et al. 2017). Ultimately, the purpose of interagency and interprofessional education and training is about improving practice that impacts positively on the care and support for people with ID who are homeless. Education programmes should prioritise early intervention and 
prevention strategies as a means to reduce the possibility of people with ID becoming homeless. Within homeless services, there is an opportunity to bring together key agencies and services to understand the roles and range of services available and promote the effective coordination of care and support to assist people with ID out of homelessness (Nishio et al, 2015a; van der Laan et al. 2018). Following exits from homelessness, education needs to focus on how agencies and services work collaboratively to fully support people with ID to prevent their possible return to homelessness. Homelessness has significant implications for society, services, families and the individual. This needs to be reflected within undergraduate and postgraduate education programmes such as social work, nursing, medicine, occupational therapy, housing, social policy and criminal justice.

\subsection{Implications for future Research}

From the current research evidence, it is apparent that multi-factorial issues exist that lead to homelessness for people with ID. Further, there are issues around population identification within homeless groups and of gaining informed consent from people with ID that can present significant challenges (van Straaten 2014; Nishio et al. 2015a; McKenzie et al. 2019). The existing studies have predominantly adopted quantitative approaches to identify prevalence figures and care and support needs. There is an absence of qualitative studies investigating the unique views and experiences through the lens of homeless people with ID. This could include their perceptions of the issues that led to homelessness, the circumstances and experiences within homeless services, and the assistance and supports necessary to successfully exit homelessness. To date there have been no long-term studies following-up people with ID once they exited homeless services. Future studies could also investigate the factors that maintain newly establish housing and support situations and what works to maintain them. Given the apparent higher prevalence of mental illness, substance misuse, sexually transmitted infections 
(STIs), human immuno-deficiency virus (HIV) and other vulnerabilities, it is important that people with ID are included in homelessness research (Williams \& Bryant, 2018). An important further area for future research is to identify the impact of family bereavement or the loss of a main carer as a contributory factor leading into homelessness and the actions necessary to mitigate against this. Further, researchers also need to identify the range of factors that lead people into homelessness and whether they are amenable to preventative strategies, supports and interventions. They need to appreciate the issues and concerns once people with ID become homeless and to identify their specific support needs within homeless services and agencies. Leading out of homelessness, there is a need to conceptualise the needs and supports that may influence and impact upon the individual's trajectory from homelessness and provide the necessary and appropriate service responses.

Future researchers need to ensure that the sub-population of people with ID are included within their study sample. To date, the existing research studies have understandably adopted convenience snowball sampling techniques with self-reporting, in an attempt to identify people with ID within homeless services. There is a need to undertake multi-centre research studies that incorporate larger samples of people with ID to inform policy and shape service developments and evidence-based practice.

\subsection{Limitations of the current review}

An important finding and strength of the current review is that family bereavement or loss of a main carer may be a significant contributory factor leading into homelessness for some people with ID. This review has several limitations which the authors acknowledge. The authors have been rigorous in the strict application of the review and analysis process. From a research perspective, there are no international multi-centre studies regarding homelessness and people with ID. Further, there are no longitudinal studies which identify the effectiveness, or not, of 
the supports provided to help people with ID to exit homelessness. Therefore, future research studies should focus on developing more rigorous approaches to population identification thereby ensuring, as far as possible, that study participants do indeed have an ID.

\section{CONCLUSIONS}

This systematic review identifies that people with ID can and do become homeless and, with appropriate supports, can successfully exit homelessness. The current systematic review of the research evidence presents new and important insights that can help develop the understanding of significant issues related to factors that may contribute to and result in homelessness for people with ID. Whilst homeless, due to their cognitive and intellectual impairment and associated needs, particular consideration and responses are required. The factors that can lead into homelessness include, having an intellectual disability, experiencing a family bereavement and loss of a main carer and the presence of mental illness, substance use and challenging behaviours. Additionally, people with ID may become homeless at an older age when compared to people without ID, often as a consequence of family bereavement or loss of a carer. The identification of people within homeless services and their subsequent care and support remain a significant challenge. Effectively identifying the homeless ID population is necessary strategically and within homelessness services is required to ensure there is access to appropriate psychosocial assessments, interventions and supports. These strategies are needed to assist people with ID to effectively exit homeless services. The critical issue relates to ensuring that there are tailored and responsive services that provide the community-based structures and supports to enable independent and fulfilling lives outside homeless services for people with ID. 


\section{Conflict of Interest}

There are no conflicts of interest.

\section{Author contributions}

$\mathrm{MB}$ and EMcC designed the study, conducted data retrieval and analysis, reported the findings and reviewed drafts and prepared and finalised the paper for publication. 


\section{REFERENCES}

Bainbridge, J., \& Carrizales, T. J. (2017). Global homelessness in a post-recession world. Journal of Public Management \& Social Policy 24(1), 6.

Busch-Geertsema, V., Culhane, D., \& Fitzpatrick, S. (2016). Developing a global framework for conceptualising and measuring homelessness. Habitat International 55, 124-132. https://doi.org/10.1016/j.habitatint.2016.03.004

Caldwell, K., Henshaw, L., \& Taylor, G. (2011). Developing a framework for critiquing health research: An early evaluation. Nurse Education Today, 31(8), e1-e7.

Clarivate Analytics (2018). EndNote X9 for Windows \& Mac, released 1 August 2018. Clarivate Analytics, Philadelphia.

Cooper, S. A., McLean, G., Guthrie, B., McConnachie, A., Mercer, S., Sullivan, F., \& Morrison, J. (2015). Multiple physical and mental health comorbidity in adults with intellectual disabilities: Population-based cross-sectional analysis. BMC Family Practice, 16(1), 110. https://doi.org/10.1186/s12875-015-0329-3

Crisis (2018). Homeless knowledge hub. https://www.crisis.org.uk/endinghomelessness/homelessness-knowledge-hub/Accessed: 12 January 2018.

Critical Appraisal Skills Programme (2013). Ten questions to help you make sense of qualitative research. Oxford: Critical Appraisal Skills Programme.

Cronin, J., \& Bourke, J. (2017). Value for money? An examination of the relationship between need and cost in intellectual disability services. Health \& Social Care in the Community, 25(3), 1227-1236. https://doi.org/10.1111/hsc.12425

Ditchman, N., Kosyluk, K., Lee, E. J., \& Jones, N. (2016). How stigma affects the lives of people with intellectual disabilities: An overview. In: Intellectual Disability and Stigma (pp. 31-47). Palgrave Macmillan, London.

Durbin, A., Isaacs, B., Mauer-Vakil, D., Connelly, J., Steer, L., Roy, S., \& Stergiopoulos, V. (2018). Intellectual Disability and Homelessness: A Synthesis of the Literature and Discussion of How Supportive Housing Can Support Wellness for People with Intellectual Disability. Current Developmental Disorders Reports, 5(3), 125-131.

https://doi.org/10.1007/s40474-018-0141-6

Emerson, E., Hatton, C., Baines, S., \& Robertson, J. (2016). The physical health of British adults with intellectual disability: Cross sectional study. International Journal for Equity in Health, 15(1), 11. doi:10.1186/s12939-016-0296-X

Gouveia, L., Massanganhe, H., Mandlate, F., Mabunda, D., Fumo, W., Mocumbi, A.O. and de Jesus Mari, J. (2017). Family reintegration of homeless in Maputo and Matola: a descriptive study. International Journal of Mental Health Systems 11(1), 25. https://doi.org/10.1186/s13033-017-0133-7 
Gowda GS, Gopika G, Kumar CN, Manjunatha N, Yadav R, Srinivas D, Dawn BR, Math SB. (2017). Clinical outcome and rehabilitation of homeless mentally ill patients admitted in mental health institute of South India:"Know the Unknown" project. Asian Journal of Psychiatry 30, 49-53. https://doi.org/10.1016/j.ajp.2017.07.001

Hourigan S., Fanaghan S. \& Caraiosa . K. (2018). Annual report of the national intellectual disability data-base committee 2017 main findings. Dublin: Health Research Board.

Hughes-McCormack, L. A., Rydzewska, E., Henderson, A., MacIntyre, C., Rintoul, J., \& Cooper, S. A. (2018). Prevalence and general health status of people with intellectual disabilities in Scotland: A total population study. Journal of Epidemiology and Community Health 72(1), 78-85. http://dx.doi.org/10.1136/jech-2017-209748

Koslowski, N., Klein, K., Arnold, K., Koesters, M., Schuetzwohl, M., Salize, H. J., \& Puschner, B. (2016). Effectiveness of interventions for adults with mild to moderate intellectual disabilities and mental health problems: Systematic review and meta-analysis. The British Journal of Psychiatry 209(6), 469-474 https://doi.org/10.1192/bjp.bp.114.162313

Levine, K. A., Proulx, J., \& Schwartz, K. (2018). Disconnected lives: Women with intellectual disabilities in conflict with the law. Journal of Applied Research in Intellectual Disabilities 31(2), 249-258. https://doi.org/10.1111/jar.12387

Mantry D, Cooper SA, Smiley E, Morrison J, Allan L, Williamson A, Finlayson J, Jackson A. (2008). The prevalence and incidence of mental ill-health in adults with Down syndrome. Journal of Intellectual Disability Research 52(2), 141-55. https://doi.org/10.1111/j.13652788.2007.00985.x

McCann, E., \& Brown, M. (2019). Homelessness among youth who identify as LGBTQ+: A systematic review. Journal of Clinical Nursing 28(11-12), 2061-2072.

https://doi.org/10.1111/jocn.14818

McKenzie, K., Murray, G., Wilson, H., \& Delahunty, L. (2019). Homelessness-It will crumble men': The views of staff and service users about facilitating the identification and support of people with an intellectual disability in homeless services. Health \& Social Care in the Community. doi.org/10.1111/hsc. 12750

Mercier C, Picard S. (2011). Intellectual disability and homelessness. Journal of Intellectual Disability Research 55(4), 441-9. https://doi.org/10.1111/j.1365-2788.2010.01366.x

Maroto M, Pettinicchio D, Patterson AC. (2019). Hierarchies of categorical disadvantage: Economic insecurity at the intersection of disability, gender, and race. Gender \& Society 33(1):64-93. https://doi.org/10.1177/0891243218794648

Moher D, Shamseer L, Clarke M, Ghersi D, Liberati A, Petticrew M,..... PRISMA-P Group (2015). Prefered reporting items for systematic review and meta-analysis protocols (PRISMA-P) 2015 statement. Systematic Reviews 4(1), 1-9. https://doi.org/10.1186/20464053-4-1 
Morton LG, Cunningham-Williams RM (2009). The capacity to give informed consent in a homeless population with developmental disabilities. Community Mental Health Journal 45(5), 341-8. doi: 10.1007/s10597-009-9184-9

Morton LG, Cunningham-Williams RM, Gardiner G. (2010). Volunteerism among homeless persons with developmental disabilities. Journal of Social Work in Disability \& Rehabilitation 9(1):12-26. doi: 10.1080/15367100903526070

Nishio A, Yamamoto M, Horita R, Sado T, Ueki H, Watanabe T, Uehara R, Shioiri T. (2015a). Prevalence of mental illness, cognitive disability, and their overlap among the homeless in Nagoya, Japan. PloS One 10(9):e0138052.

https://doi.org/10.1371/journal.pone.0138052

Nishio A, Yamamoto M, Ueki H, Watanabe T, Matsuura K, Tamura O, Uehara R, Shioiri T.(2015b). Prevalence of mental illness, intellectual disability, and developmental disability among homeless people in Nagoya, Japan: A case series study. Psychiatry and Clinical Neurosciences 69(9):534-42. doi: 10.1111/pcn.12265

Nishio A, Horita R, Sado T, Mizutani S, Watanabe T, Uehara R, Yamamoto M. (2017). Causes of homelessness prevalence: Relationship between homelessness and disability. Psychiatry and Clinical Neurosciences 71(3):180-8. doi: 10.1111/pcn.12469.

Oakes PM, Davies RC. (2008). Intellectual disability in homeless adults: A prevalence study. Journal of Intellectual Disabilities 12(4), 325-34. doi: 10.1177/1744629508100496.

Park, E. Y., Nam, S. J., \& Park, S. H. (2017). Income Patterns of Households Including Individuals with Intellectual Disabilities According to Poverty Dynamics. Journal of Policy and Practice in Intellectual Disabilities 14(2), 108-117. https://doi.org/10.1111/jppi.12166

Pelleboer-Gunnink, H. A., Van Oorsouw, W. M. W. J., Van Weeghel, J., \& Embregts, P. J. C. M. (2017). Mainstream health professionals' stigmatising attitudes towards people with intellectual disabilities: A systematic review. Journal of Intellectual Disability Research, 61(5), 411-434. doi.org/10.1111/jir.12353

Phipps, M., Dalton, L., Maxwell, H., \& Cleary, M. (2019). Women and homelessness, a complex multidimensional issue: findings from a scoping review. Journal of Social Distress and the Homeless 28(1), 1-13. https://doi.org/10.1080/10530789.2018.1534427

Piat, M., Polvere, L., Kirst, M., Voronka, J., Zabkiewicz, D., Plante, M.C., Isaak, C., Nolin, D., Nelson, G. and Goering, P. (2015). Pathways into homelessness: Understanding how both individual and structural factors contribute to and sustain homelessness in Canada. Urban Studies 52(13), 2366-2382. https://doi.org/10.1177/0042098014548138

Robertson, J., Hatton, C., Emerson, E., \& Baines, S. (2014). The impact of health checks for people with intellectual disabilities: An updated systematic review of evidence. Research in Developmental Disabilities 35(10), 2450-2462. https://doi.org/10.1016/j.ridd.2014.06.007

Rushbrooke, E., Murray, C., \& Townsend, S. (2014). The experiences of intimate relationships by people with intellectual disabilities: A qualitative study. Journal of Applied Research in Intellectual Disabilities 27(6):531-541. https://doi.org/10.1111/jar.12091 
Salmon, N., Garcia Iriarte, E., Donohoe, B., Murray, L., Singleton, G., Barrett, M., \& Dillon, M. (2019). Our Homes: An inclusive study about what moving house is like for people with intellectual disabilities in Ireland. British Journal of Learning Disabilities 47(1), 19-28. https://doi.org/10.1111/bld.12251

Shankland, J., \& Dagnan, D. (2015). IAPT practitioners' experiences of providing therapy to people with intellectual disabilities. Advances in Mental Health and Intellectual Disabilities, 9(4), 206-214. https://doi.org/10.1108/AMHID-02-2015-0008

Spence S., Stevens R. \& Parks R. (2017). Cognitive dysfunction in homeless adults: a systematic review. Journal of the Royal Society of Medicine 97(8), 375-9. https://doi.org/10.1177/014107680409700804

Stone, B., Dowling, S., \& Cameron, A. (2019). Cognitive impairment and homelessness: A scoping review. Health \& Social Care in the Community, 27(4), e125-e142. https://doi.org/10.1111/hsc. 12682

Truesdale, M. \& Brown, M. (2017). People with Learning Disabilities in Scotland: Health Needs Assessment Update Report 2017. Glasgow: NHS Health Scotland.

van der Laan J, van Straaten B, Boersma SN, Rodenburg G, van de Mheen D, Wolf JR. (2018). Predicting homeless people's perceived health after entering the social relief system in The Netherlands. International Journal of Public Health 63(2):203-11. https://doi.org/10.1007/s00038-017-1026-x

van Dongen, S. I., van Straaten, B., Wolf, J. R., Onwuteaka-Philipsen, B. D., van der Heide, A., Rietjens, J. A., \& van de Mheen, D. (2019). Self-reported health, healthcare service use and health-related needs: A comparison of older and younger homeless people. Health \& Social Care in the Community. http://doi.org/10.1111/hsc.12739

van Straaten B, Schrijvers CT, van der Laan J, Boersma SN, Rodenburg G, Wolf JR, Van de Mheen D. (2014). Intellectual disability among Dutch homeless people: prevalence and related psychosocial problems. PLoS One 9(1):e86112.

https://doi.org/10.1371/journal.pone.0086112

van Straaten B, Rodenburg G, van der Laan J, Boersma SN, Wolf JR, van de Mheen D. (2017). Self-reported care needs of Dutch homeless people with and without a suspected intellectual disability: a 1.5-year follow-up study. Health \& Social Care in the Community 25(1):123-36. https://doi.org/10.1111/hsc.12287

Whittle, E. L., Fisher, K. R., Reppermund, S., Lenroot, R., \& Trollor, J. (2018). Barriers and enablers to accessing mental health services for people with intellectual disability: A scoping review. Journal of Mental Health Research in Intellectual Disabilities 11(1), 69-102. https://doi.org/10.1080/19315864.2017.1408724

Whittle, E. L., Fisher, K. R., Reppermund, S., \& Trollor, J. (2019). Access to mental health services: The experiences of people with intellectual disabilities. Journal of Applied Research in Intellectual Disabilities, 32(2), 368-379. http://doi.org/10.1111/jar.12533 
Williams, S. P., \& Bryant, K. L. (2018). Sexually transmitted infection prevalence among homeless adults in the United States: A systematic literature review. Sexually Transmitted Diseases, 45(7), 494.

Williamson, H. J., Contreras, G. M., Rodriguez, E. S., Smith, J. M., \& Perkins, E. A. (2017). Health care access for adults with intellectual and developmental disabilities: A scoping review. OTJR: Occupation, Participation and Health 37(4), 227-236.

https://doi.org/10.1177/1539449217714148

Wilson, S., McCloughen A, Parr J, Jackson D. (2019). "If you are homeless you are welcome here": Social obligations for the homeless and socially disadvantaged. Journal of Clinical Nursing 28(15-16), 2721-2723. https://doi.org/10.1111/jocn.14851

Woodman, A. C., Mailick, M. R., Anderson, K. A., \& Esbensen, A. J. (2014). Residential transitions among adults with intellectual disability across 20 years. American Journal on Intellectual and Developmental Disabilities 119(6), 496-515. http://doi:10.1352/1944-7558119.6.496.

World Health Organisation (2018). WHO Housing and Health Guidelines. Geneva: WHO. 
Table 1: CINAHL search strategy

\begin{tabular}{|l|l|c|}
\hline Search code & Query & Results \\
\hline S1 & Intellectual disab* & 21,600 \\
\hline S2 & Mental retard* & 2,939 \\
\hline S3 & Developmental disab* & 10,030 \\
\hline S4 & Mental handicap* & 438 \\
\hline S5 & Learning disab* & 7,537 \\
\hline S6 & Homeless* & 9,488 \\
\hline S7 & Homeless persons & 4,907 \\
\hline S8 & $\begin{array}{l}\text { S1 OR S2 OR S3 OR S4 } \\
\text { OR S5 }\end{array}$ & 35,355 \\
\hline S9 & S6 OR S7 & 9,488 \\
\hline S10 & S8 AND S9 & 59 \\
\hline S11 & $\begin{array}{l}\text { Limiters: English, peer } \\
\text { reviewed articles }\end{array}$ & \\
\hline
\end{tabular}


Table 2: Papers included in the review $(n=13)$

\begin{tabular}{|c|c|c|c|c|c|}
\hline $\begin{array}{l}\text { Study Citation } \\
\text { and Country }\end{array}$ & Aims & Sample & $\begin{array}{l}\text { Data collection } \\
\text { design \& methods }\end{array}$ & Key Findings & Recommendations \\
\hline $\begin{array}{l}\text { Oakes \& Davies } \\
(2008) \\
\text { UK }\end{array}$ & $\begin{array}{l}\text { Identify the } \\
\text { prevalence of ID } \\
\text { within a homeless } \\
\text { population. }\end{array}$ & $\begin{array}{l}\text { Homeless people } \\
(n=50) \\
\text { ID }(n=6)\end{array}$ & $\begin{array}{l}\text { Cross-section design } \\
\text { using case records, } \\
\text { interviews and } \\
\text { standardized scales }\end{array}$ & $\begin{array}{l}\text { More people with ID were found } \\
\text { to be homeless in this study } \\
\text { compared to the general } \\
\text { population. Following full IQ } \\
\text { testing, six of the study } \\
\text { participants had a diagnosable ID. } \\
\text { Significant cognitive impairment } \\
\text { and educational deficits and } \\
\text { development needs were } \\
\text { identified. A diagnosis of ID is a } \\
\text { potential risk factor for } \\
\text { homelessness. }\end{array}$ & $\begin{array}{l}\text { Further research is required to } \\
\text { identify effective interventions and } \\
\text { supports for people with ID who are } \\
\text { homeless and may be difficult to } \\
\text { identify. Practitioners need to be } \\
\text { aware of specific issues affecting } \\
\text { people with ID who are homeless. } \\
\text { Use of validated assessment tools in } \\
\text { routine practice to identify ID and } \\
\text { specific support needs required. } \\
\text { Need to be improved interagency } \\
\text { and service collaborations. }\end{array}$ \\
\hline $\begin{array}{l}\text { Morton \& } \\
\text { Cunningham- } \\
\text { Williams (2009) } \\
\text { USA }\end{array}$ & $\begin{array}{l}\text { Examine the capacity } \\
\text { to consent in } \\
\text { homeless people with } \\
\text { ID using a capacity- } \\
\text { to-consent screening } \\
\text { tool }\end{array}$ & $\begin{array}{l}\text { People with ID } \\
(n=62)\end{array}$ & $\begin{array}{l}\text { Cross-section design } \\
\text { using semi-structured } \\
\text { interviews }\end{array}$ & $\begin{array}{l}\text { People with ID had enduring } \\
\text { homeless issues with a mean age } \\
\text { was } 32 \text { years; the majority were } \\
\text { African-American and male. } 55 \\
\text { per cent were unemployed and } 60 \\
\text { per cent living on the streets. } 40 \\
\text { per cent experienced long-term } \\
\text { homelessness. Half of the sample } \\
\text { unable to give informed consent to }\end{array}$ & $\begin{array}{l}\text { More enabling approach to obtaining } \\
\text { consent that protects and assists } \\
\text { people with ID with capacity issues } \\
\text { and complex decision-making is } \\
\text { required. Further research needed } \\
\text { regarding the prevalence of } \\
\text { homeless in ID populations and } \\
\text { psychosocial issues. Researchers } \\
\text { need to be sensitive to and adapt } \\
\text { consenting procedures to be able to } \\
\text { include people with ID in research }\end{array}$ \\
\hline
\end{tabular}




\begin{tabular}{|c|c|c|c|c|c|}
\hline & & & & $\begin{array}{l}\text { participate in research, many due } \\
\text { to low educational attainment. }\end{array}$ & $\begin{array}{l}\text { studies. Access to school records } \\
\text { may assist in the assessment } \\
\text { process. }\end{array}$ \\
\hline $\begin{array}{l}\text { Morton et al. } \\
(2010) \\
\text { USA }\end{array}$ & $\begin{array}{l}\text { Identify whether } \\
\text { volunteerism among } \\
\text { homeless people in } \\
\text { ID services supports } \\
\text { community } \\
\text { integration }\end{array}$ & $\begin{array}{l}\text { People with ID } \\
(\mathrm{n}=60)\end{array}$ & $\begin{array}{l}\text { Cross-section design } \\
\text { using semi-structured } \\
\text { interviews }\end{array}$ & $\begin{array}{l}\text { Sample mainly male, African- } \\
\text { American }(93 \%) \text {, low educational } \\
\text { attainment. Homeless ID people } \\
\text { volunteer more than the general } \\
\text { population in church meal } \\
\text { programmes as means of giving } \\
\text { back rather than developing } \\
\text { employment skills. Visiting } \\
\text { friends or family monthly } \\
\text { increased volunteering, } \\
\text { unemployment decreased } \\
\text { volunteering. Volunteering } \\
\text { supports healthy community } \\
\text { integration. }\end{array}$ & $\begin{array}{l}\text { There is a need for qualitative } \\
\text { research to identify possible benefits } \\
\text { of volunteering for people with IDD } \\
\text { who are homeless. Further research } \\
\text { required on substance use and } \\
\text { mental illness in ID volunteers to } \\
\text { identify potential impact and } \\
\text { supports required. }\end{array}$ \\
\hline $\begin{array}{l}\text { Mercier \& Picard } \\
\text { (2011) } \\
\text { Canada }\end{array}$ & $\begin{array}{l}\text { Identify the } \\
\text { characteristics, } \\
\text { history and current } \\
\text { living situation of } \\
\text { homeless people with } \\
\text { ID. }\end{array}$ & $\begin{array}{l}\text { People with ID } \\
(\mathrm{n}=68)\end{array}$ & $\begin{array}{l}\text { Case study design } \\
\text { using case records }\end{array}$ & $\begin{array}{l}\text { People with ID have multiple } \\
\text { issues that lead to homelessness. } \\
63 \% \text { were men, } 30 \% \text { women, } \\
\text { mean age was } 43 \text { years. } 78 \% \text { had } \\
\text { attended special education } \\
\text { provision, } 63 \% \text { homeless for more } \\
\text { that } 4 \text { years. Mental illness }(60 \%) \text {, } \\
\text { substance misuse }(56 \%) \text {, physical }\end{array}$ & $\begin{array}{l}\text { More homelessness prevention } \\
\text { programmes needed and } \\
\text { intervention and support strategies } \\
\text { required. Further public health } \\
\text { research needed regarding } \\
\text { homelessness and ID. More } \\
\text { epidemiological studies needed to } \\
\text { identify the risks associated with }\end{array}$ \\
\hline
\end{tabular}




\begin{tabular}{|c|c|c|c|c|c|}
\hline & & & & $\begin{array}{l}\text { health issues }(43 \%) \text {, relationship } \\
\text { breakdown }(31 \%) \text {, criminal justice } \\
\text { contact }(31 \%) \text { were key issues. } \\
\text { Women have shorter periods of } \\
\text { homelessness compared to men. } \\
\text { Once identified as having ID with } \\
\text { homeless service, their situation } \\
\text { improved with support. }\end{array}$ & $\begin{array}{l}\text { homelessness and intellectual } \\
\text { functioning. }\end{array}$ \\
\hline $\begin{array}{l}\text { Van Straaten et al. } \\
(2014) \\
\text { Netherlands }\end{array}$ & $\begin{array}{l}\text { Identify prevalence } \\
\text { of homelessness in } \\
\text { Dutch people with ID } \\
\text { and the relationship } \\
\text { with psychosocial } \\
\text { issues }\end{array}$ & $\begin{array}{l}\text { Homeless adults } \\
(\mathrm{n}=387) \\
\text { ID }(\mathrm{n}=114)\end{array}$ & $\begin{array}{l}\text { Cross-section design } \\
\text { using interviews and } \\
\text { standardized scales }\end{array}$ & $\begin{array}{l}\text { More homeless males with ID and } \\
\text { higher than the general population. } \\
\text { Low education attainment. Higher } \\
\text { somatization rates and depression } \\
\text { in ID people, with more stress in } \\
\text { older participants. Twice as likely } \\
\text { to have substance misuse issues. } \\
\text { Alcohol use most commonly used } \\
\text { substance. Links between } \\
\text { substance misuse and mental } \\
\text { health issues. Greater vulnerability } \\
\text { and risk factors among homeless } \\
\text { ID. }\end{array}$ & $\begin{array}{l}\text { Screening required to identify } \\
\text { people with ID who are homeless. } \\
\text { Need greater psychosocial } \\
\text { treatments, supports, and special } \\
\text { housing support. Require specialist } \\
\text { ID professional input based within } \\
\text { homeless services. Customised } \\
\text { support programmes and specialist } \\
\text { housing may be needed. }\end{array}$ \\
\hline
\end{tabular}




\begin{tabular}{|c|c|c|c|c|c|}
\hline $\begin{array}{l}\text { Nishio et al. } \\
(2015 \mathrm{a}) \\
\text { Japan }\end{array}$ & $\begin{array}{l}\text { Explore the } \\
\text { prevalence of mental } \\
\text { illness and ID among } \\
\text { homeless people in } \\
\text { Japan }\end{array}$ & $\begin{array}{l}\text { Homeless men } \\
(\mathrm{n}=18) \\
\text { ID }(n=7)\end{array}$ & $\begin{array}{l}\text { Cross-section design } \\
\text { using interviews and } \\
\text { standardized scales }\end{array}$ & $\begin{array}{l}\text { Men with ID became homeless on } \\
\text { average at the age of } 54 \text { years } \\
\text { compared to } 59 \text { years in the non- } \\
\text { ID population. Over } 70 \% \text { of ID } \\
\text { people also had mental health } \\
\text { issues including alcohol } \\
\text { dependence, depression, mood } \\
\text { disorder and PTSD. }\end{array}$ & $\begin{array}{l}\text { Increased support necessary, } \\
\text { including psychological therapies } \\
\text { and treatments to address homeless } \\
\text { issues specific to people with ID. }\end{array}$ \\
\hline $\begin{array}{l}\text { Nishio et al. } \\
(2015 b) \\
\text { Japan }\end{array}$ & $\begin{array}{l}\text { Investigate the } \\
\text { prevalence of mental } \\
\text { illness and ID in } \\
\text { homeless people in } \\
\text { Japan. }\end{array}$ & $\begin{array}{l}\text { Homeless people } \\
(n=114) \\
\text { ID }(n=39)\end{array}$ & $\begin{array}{l}\text { Cross-section design } \\
\text { using interviews and } \\
\text { standardized scales }\end{array}$ & $\begin{array}{l}42 \% \text { of all participants had mental } \\
\text { illness. } 16 \% \text { had mental illness } \\
\text { and ID including schizophrenia, } \\
\text { mood disorder, anxiety disorder, } \\
\text { substance use and personality } \\
\text { disorder. People with ID smoke } \\
\text { more. Only people with ID } \\
\text { reported wanting to remain } \\
\text { homeless. }\end{array}$ & $\begin{array}{l}\text { Need appropriate psychosocial } \\
\text { strategies, interventions and } \\
\text { supports specific to the needs of } \\
\text { people with ID within homeless } \\
\text { services to address their mental } \\
\text { health and psychological issues and } \\
\text { concerns. }\end{array}$ \\
\hline $\begin{array}{l}\text { Gouveia et al. } \\
(2017) \\
\text { Mozambique }\end{array}$ & $\begin{array}{l}\text { Explore mental } \\
\text { health status of } \\
\text { homeless people } \\
\text { including people with } \\
\text { an intellectual } \\
\text { disability (ID). }\end{array}$ & $\begin{array}{l}\text { Homeless people } \\
(n=71) \text { : } \\
\text { ID }(n=4)\end{array}$ & $\begin{array}{l}\text { Cross-section design } \\
\text { using interviews and } \\
\text { standardized scales }\end{array}$ & $\begin{array}{l}\text { People with ID had less successful } \\
\text { family re-integration. Burden, } \\
\text { shame and stigma were possible } \\
\text { influencing factors. Transcultural } \\
\text { interpretations were significant. }\end{array}$ & $\begin{array}{l}\text { Need integrated and well co- } \\
\text { ordinated supports for people with } \\
\text { ID who are homeless. Further } \\
\text { research required to fully understand } \\
\text { homelessness, support needs and } \\
\text { possible psychosocial interventions. }\end{array}$ \\
\hline
\end{tabular}




\begin{tabular}{|c|c|c|c|c|c|}
\hline $\begin{array}{l}\text { Gowda et al. (2017) } \\
\text { India }\end{array}$ & $\begin{array}{l}\text { Examine case files of } \\
\text { homeless mental ill } \\
\text { patients, including } \\
\text { people with ID, } \\
\text { admitted to mental } \\
\text { health services in } \\
\text { India. }\end{array}$ & $\begin{array}{l}\text { Patients }(n=78) \\
\text { ID }(n=24)\end{array}$ & $\begin{array}{l}\text { Case study design } \\
\text { using case records }\end{array}$ & $\begin{array}{l}\text { Patients with ID were negatively } \\
\text { co-related with family } \\
\text { reintegration. Unable to trace the } \\
\text { fail in } 55 \% \text { of cases. People with } \\
\text { ID may be unable to verbalise } \\
\text { their original home address and } \\
\text { therefore remain unintegrated back } \\
\text { into the family home. }\end{array}$ & $\begin{array}{l}\text { Need for national services strategy } \\
\text { and plan for people with ID who are } \\
\text { homeless to identify and address } \\
\text { socioeconomic, health and human } \\
\text { rights issues that result in } \\
\text { homelessness. }\end{array}$ \\
\hline $\begin{array}{l}\text { Nishio et al. (2017) } \\
\text { Japan }\end{array}$ & $\begin{array}{l}\text { Investigate the } \\
\text { relationship between } \\
\text { homelessness and ID. }\end{array}$ & $\begin{array}{l}\text { Homeless people } \\
(n=114) \\
\text { ID }(n=39)\end{array}$ & $\begin{array}{l}\text { Cross-section design } \\
\text { using interviews and } \\
\text { standardized scales }\end{array}$ & $\begin{array}{l}34 \% \text { had an ID and } 16 \% \text { had ID } \\
\text { and mental illness. Poor family } \\
\text { relationships led to homelessness } \\
\text { for people with ID. People with } \\
\text { mental illness and poor } \\
\text { relationships more prone to } \\
\text { homelessness and get trapped. ID } \\
\text { and homelessness linked to low } \\
\text { educational attainment. }\end{array}$ & $\begin{array}{l}\text { Improved access to supported } \\
\text { housing appropriate to the needs of } \\
\text { people with ID required. Access to } \\
\text { mental health treatments and } \\
\text { assertive community treatment } \\
\text { programmes and employment } \\
\text { needed. }\end{array}$ \\
\hline $\begin{array}{l}\text { Van Straaten et al. } \\
\text { (2017) } \\
\text { Netherlands }\end{array}$ & $\begin{array}{l}\text { Identify self-report } \\
\text { care needs of Dutch } \\
\text { homeless people: } \\
\text { Follow-up study. }\end{array}$ & $\begin{array}{l}\text { Homeless adults } \\
(n=336) \\
\text { IDD }(n=104)\end{array}$ & $\begin{array}{l}\text { Cross-section design } \\
\text { using interviews and } \\
\text { standardized scales }\end{array}$ & $\begin{array}{l}\text { Mean age } 41 \text { years. } 31 \% \text { had a } \\
\text { suspected ID. } 85 \% \text { male. } 82 \% \text { had } \\
\text { low education attainment. } 33 \% \\
\text { using mental health services. } 69 \% \\
\text { needed access to medical care. } \\
24 \% \text { used housing support } \\
\text { services. Care and support of } \\
\text { homeless people with IDD } \\
\text { requires to be ongoing with a } \\
\text { desire to live independently after } \\
\text { exiting homelessness. Becoming }\end{array}$ & $\begin{array}{l}\text { There is a need for more } \\
\text { psychosocial and physical } \\
\text { interventions to address the } \\
\text { increasing problems faced by people } \\
\text { with ID who are homeless. }\end{array}$ \\
\hline
\end{tabular}




\begin{tabular}{|c|c|c|c|c|c|}
\hline & & & & $\begin{array}{l}\text { homeless at an older age and being } \\
\text { male are significant factors. } \\
\text { Reduction in unmet care needs } \\
\text { when support services are } \\
\text { provided. }\end{array}$ & \\
\hline $\begin{array}{l}\text { Van der Laan et al. } \\
\text { (2018) } \\
\text { Netherlands }\end{array}$ & $\begin{array}{l}\text { Explore the } \\
\text { perceived health } \\
\text { needs in homeless } \\
\text { people. }\end{array}$ & $\begin{array}{l}\text { Homeless adults } \\
(\mathrm{n}=344) \\
\operatorname{ID}(\mathrm{n}=102)\end{array}$ & $\begin{array}{l}\text { Cross-section design } \\
\text { using interviews and } \\
\text { standardized scales }\end{array}$ & $\begin{array}{l}31 \% \text { if participants had a } \\
\text { suspected ID. Improvements in } \\
\text { health, income, work and social } \\
\text { supports were identified. } \\
\text { Decrease in unmet care needs, } \\
\text { police arrests, alcohol and } \\
\text { cannabis use and distress when } \\
\text { supports provided. }\end{array}$ & $\begin{array}{l}\text { Greater psychosocial supports } \\
\text { required by people with ID who are } \\
\text { homeless to address psychological } \\
\text { needs and substance use. }\end{array}$ \\
\hline $\begin{array}{l}\text { McKenzie et al. } \\
\text { (2019) } \\
\text { United Kingdom }\end{array}$ & $\begin{array}{l}\text { Identify the views of } \\
\text { staff and people with } \\
\text { ID regarding support } \\
\text { needs and the use of } \\
\text { an ID screening } \\
\text { questionnaire. }\end{array}$ & $\begin{array}{l}\text { People with ID } \\
(\mathrm{n}=8) \\
\text { Support staff } \\
(\mathrm{n}=16)\end{array}$ & $\begin{array}{l}\text { Cross-section design } \\
\text { using interviews }\end{array}$ & $\begin{array}{l}\text { Using a screening tool may } \\
\text { identify specialist assessment and } \\
\text { support needs and provide } \\
\text { evidence regarding prevalence of } \\
\text { ID homelessness. }\end{array}$ & $\begin{array}{l}\text { Staff development programmes are } \\
\text { required regarding the needs of } \\
\text { people with ID. Further research is } \\
\text { required using screening } \\
\text { questionnaires to systematically } \\
\text { identify prevalence and support } \\
\text { needs to inform policy and service } \\
\text { delivery. }\end{array}$ \\
\hline
\end{tabular}


Table 3: CASP quality scores $(n=13)$

\begin{tabular}{|c|c|c|c|c|c|c|c|c|c|c|c|c|c|}
\hline $\begin{array}{l}\text { CASP } \\
\text { criteria }\end{array}$ & $\begin{array}{l}\text { Oakes \& } \\
\text { Davies } \\
(2008)\end{array}$ & $\begin{array}{l}\text { Morton \& } \\
\text { Cunningham- } \\
\text { Williams } \\
\text { (2009) }\end{array}$ & $\begin{array}{l}\text { Morton } \\
\text { et al. } \\
\text { (2010) }\end{array}$ & $\begin{array}{l}\text { Mercier \& } \\
\text { Picard } \\
(2011)\end{array}$ & $\begin{array}{l}\text { Van Straaten } \\
\text { et al. (2014) }\end{array}$ & $\begin{array}{l}\text { Nishio } \\
\text { et al. } \\
(2015 \mathrm{a})\end{array}$ & $\begin{array}{l}\text { Nishio } \\
\text { et al. } \\
\text { (2015b) }\end{array}$ & $\begin{array}{l}\text { Gouveia } \\
\text { et al. } \\
\text { (2017) }\end{array}$ & $\begin{array}{l}\text { Gowda } \\
\text { et al. } \\
\text { (2017) }\end{array}$ & $\begin{array}{l}\text { Nishio et } \\
\text { al. } \\
(2017)\end{array}$ & $\begin{array}{l}\text { Van Straaten } \\
\text { et al. (2017) }\end{array}$ & $\begin{array}{l}\text { Van der Laan } \\
\text { et al. (2018) }\end{array}$ & $\begin{array}{l}\text { McKenzie } \\
\text { et al. (2019) }\end{array}$ \\
\hline $\begin{array}{l}\text { 1. Clear } \\
\text { statement of } \\
\text { aims }\end{array}$ & 2 & 2 & 2 & 2 & 2 & 2 & 2 & 2 & 2 & 2 & 2 & 2 & 2 \\
\hline $\begin{array}{l}2 . \\
\text { Appropriate } \\
\text { methodology }\end{array}$ & 1 & 2 & 1 & 1 & 2 & 2 & 2 & 2 & 1 & 2 & 2 & 2 & 2 \\
\hline $\begin{array}{l}3 . \\
\text { Appropriate } \\
\text { research } \\
\text { design }\end{array}$ & 1 & 2 & 2 & 1 & 2 & 2 & 2 & 1 & 1 & 2 & 2 & 2 & 2 \\
\hline $\begin{array}{l}4 . \\
\text { Appropriate } \\
\text { recruitment } \\
\text { strategy }\end{array}$ & 1 & 1 & 1 & 0 & 1 & 1 & 1 & 1 & 0 & 1 & 1 & 1 & 2 \\
\hline $\begin{array}{l}5 . \\
\text { Appropriate } \\
\text { data } \\
\text { collection } \\
\text { methods }\end{array}$ & 2 & 2 & 2 & 1 & 2 & 2 & 2 & 1 & 1 & 2 & 2 & 2 & 2 \\
\hline $\begin{array}{l}\text { 6. Research } \\
\text { relationships } \\
\text { considered }\end{array}$ & 0 & 0 & 0 & 0 & 0 & 0 & 0 & 0 & 0 & 0 & 0 & 0 & 0 \\
\hline $\begin{array}{l}\text { 7. Consider } \\
\text { ethical } \\
\text { issues }\end{array}$ & 2 & 2 & 2 & 2 & 2 & 2 & 2 & 2 & 2 & 2 & 2 & 2 & 2 \\
\hline $\begin{array}{l}\text { 8. Rigorous } \\
\text { analysis }\end{array}$ & 2 & 2 & 2 & 2 & 2 & 2 & 2 & 2 & 2 & 2 & 2 & 2 & 2 \\
\hline $\begin{array}{l}\text { 9. Clear } \\
\text { findings }\end{array}$ & 2 & 2 & 2 & 2 & 2 & 2 & 2 & 2 & 2 & 2 & 2 & 2 & 2 \\
\hline $\begin{array}{l}\text { 10. Value of } \\
\text { the research }\end{array}$ & 2 & 2 & 2 & 2 & 2 & 2 & 2 & 2 & 2 & 2 & 2 & 2 & 2 \\
\hline $\begin{array}{l}\text { Total from a } \\
\text { possible } 20\end{array}$ & 15 & 17 & 16 & 13 & 17 & 17 & 17 & 15 & 13 & 17 & 17 & 17 & 18 \\
\hline
\end{tabular}


